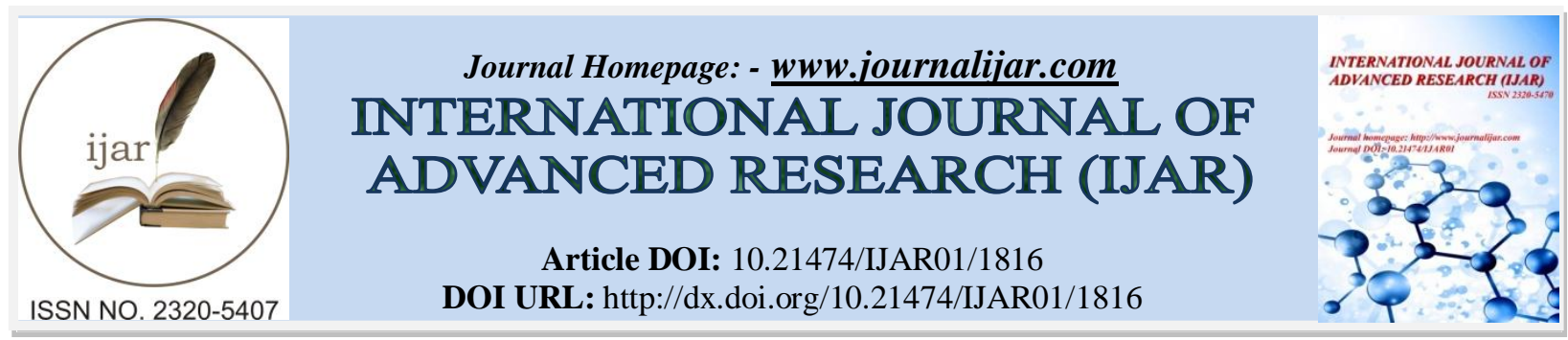

RESEARCH ARTICLE

\title{
RELATIVE STUDY OF HEAVY METALS COPPER AND NICKEL ON THE BLOOD CELLS OF AQUATIC LIFE.
}

Dr. Alkesh I. Shah.

Associate Professor \& Head, Zoology Department, B. P. Baria Science Institute, Navsari - 396445, Gujarat, India.

\section{Manuscript Info}

Manuscript History

Received: 14 August 2016

Final Accepted: 22 September 2016

Published: October 2016

Key words:-

Heavy metal, Copper, Nickel, Toxicity,

Labeo rohita

\section{Abstract}

Heavy metal pollution in soil and water has severely affected the environment. These metals in environment are transferred into physico - chemical forms that are highly toxic and hazardous to aquatic life and humans. The present study is based on the Indian major carp ( Labeo rohita) being the prime cultured species in poly culture practices in India. Hence the impact of heavy metal on the cellular level of this candidate species was chosen for the study. To prove this the fish Labeo rohita was subjected to different heavy metal concentrations of Copper and Nickel and hematological alterations were observed in different target sites like blood and muscles. Structural alterations were observed in blood cells of the fish exposed to heavy metals in different concentrations of ppm. Blood smear prepared from fish was stained with Leishmann's stain and different deformities were observed like cell membrane damage, vacullation, reduction in nucleus size, nucleus shifting, wrinkling of the membrane etc. This leads to fish poisoning and its nutritive value is also lowered. The results suggests that its prime time when different methods should be adopted to check metal pollution in water.

Copy Right, IJAR, 2016,. All rights reserved.

\section{Introduction:-}

Heavy metal pollution in water indicates the presence of unnatural substances in the environment especially in soil and water at a level that causes undesirable effects. Discharge of industrial effluents either directly into water bodies or on to land has posed a serious pollution problem which is on the rise with the growth of industries and human population. Contamination of water with heavy metals may lead to cultural eutrophication, elimination of all living organisms etc. The effect of sewage, industrial wastes and agricultural drainage on plant and animal life in close bodies of water is sometimes catastrophic. Millions of tons of fish are killed every year by a wide variety of different pollutants from different sources like municipal, domestic and industrial. The waste products in this water have long range effects on public health via food chain. Several different criteria have been defined, primarily on the basis of observed effects on aquatic life ${ }^{1}$.

Metal pollution from multifarious sources like effluents from industries, agriculture runoff and untreated sewage system has adverse effect on aquatic ecosystem. The metal contamination in aquatic ecosystem is yet considered to be unsafe not only for the human beings, but also for the wild organisms. Fish living in the metal contaminated water may accumulate toxic trace metals via their food ${ }^{9}$. Heavy metals are taken up through different organs of fish because of the affinity between them ${ }^{7}$. In this process, many heavy metals are concentrated at different levels in 
different organs of the body ${ }^{3,11,12}$. The liver is highly active in the uptake and storage of heavy metals, hence it is good monitors of water pollution with metals since their concentration are proportional to those present in the environment ${ }^{6}$. Though fish liver is seldom consumed fish liver may represent a good biomonitoring of metal pollution ${ }^{5}$. The deleterious effects of metals on aquatic ecosystem necessitate the continuous monitoring of their accumulation in key species, since it affords indication of temporal and spatial extent of the process and impact on the health of the organism ${ }^{\mathbf{8}}$. The heavy metals contamination is one of the vital factors for decline of water quality that has an obvious impact on fish diversity. Consumption of fish from the contaminated site poses a higher health risk to human.

Copper occurs in copper plating wastes, copper pickling liquors and in effluents from copper mining operations. Nickel is added into water by manufacturing of stainless steel and its alloys, as a catalyst ion and food processing units. Burning of natural coal in industrial bodies, natural erosion of rocks due to strong winds, combustion of petroleum products causes release of nickel salts like nickel chloride, nickel sulphate and nickel nitrate in atmosphere.

The metallic solutions from the industries are toxic and inhibit self purification of rivers. In addition to it aquatic plants and animals also get killed. Contamination of rivers by toxic metals prevents further use of water for industrial and drinking purpose. These toxic materials may cause chromosome damage and create hindrance to the natural process of heredity. Heavy metal ions precipitate in the mucous secretion of the gills in fish. These precipitates occupy the inter lamellar space, leading to the decrease in the movement of the gill filaments and thus partially or fully preventing respiration. Copper in about 2 parts per hundred million parts of water is fatal to fish and other organisms, where as the lethal concentration of nickel is about $1 \mathrm{ppm}$.

The main aim is to access the effect of copper and nickel in fresh water edible fish Labeo rohita, also known as major carp. Copper has essentially been a beneficial element in human metabolism. In human serum the normal copper level to be maintained is $120-140 \mu \mathrm{g} / \mathrm{lit}$. If the level rises above this range it can be identified as copper toxicity ${ }^{2}$. A deficiency of copper gives rise to nutritional problems in infants. Copper imparts some undesirable taste to water and can be been detected in range from 1 to $5 \mathrm{ppm}$. Copper concentration more than $20 \mu \mathrm{g} / \mathrm{gm}$ can prove to be toxic ${ }^{4,14}$. Small amounts are not generally considered to be toxic, but very large doses may cause sickness, and in extreme cases may lead to liver damage. During the use of copper sulphate in a surface water supply for algal control, the levels have to be closely monitored and controlled. Copper in small amounts does not constitute a health hazard but imparts an undesirable taste to drinking water. Copper occurs in copper plating wastes and copper pickling liquors. Copper compounds are toxic to fish and other aquatic life and microorganisms ${ }^{13}$.

The presence of copper in the plant and animal tissue has been recognized more than 150 years ago. Long before, it was recognized as an essential element in the diets of birds and mammals. This continues even in human physiological functions in the synthesis of proteins. The insufficiency of copper in the human body leads to severe health related problems like skin diseases including leukoderma, nerve in-capabilities and blood flow in the arteries. But when this uptake of copper by a human exceeds a minimum level, then a number of health related problems will crop up. Copper traces released from copper vessels or pipes can cause gastrointestinal disturbances, and inhalation of copper fumes can cause metal fume fever.

Nickel is another element whose presence in traces is necessary for the growth of all living entities. When the amount exceeds the tolerance limits of that particular living being, then the resultant effect creates impediments in the growth or even leads to fatal consequences. Excessive presence of nickel also plays a key role in hampering the growth of fish Labeo rohita. Nickel is used by industries associated with different trades. Nickel finds its use in the manufacturing of stainless steel, and its alloys; and also as a catalyst in food processing units. Nickel salts like nickel chloride, nickel sulphate and nickel nitrate are widely used in many processes. It is present in soil, air, water and all living material. It is the $24^{\text {th }}$ most widely found element in the whole world. Burning of natural coal in industrial boilers, natural erosion of rocks due to strong winds, combustion of petroleum products are the causes of release of nickel salts in the atmosphere. Tobacco also contains nickel, and its smoking results in the direct addition of excessive nickel content in the body of the smoker. The same concentration of nickel in drinking water is 10 $\mu \mathrm{g} / \mathrm{liter}$. Effluents laden with nickel salts pollute the water of the rivers thus disturbing the eco system and the organisms that rely on it; animals and human population who thrive on the river water. These effluents are from the human settlements that thrive in cities and near industrial zones and the industries themselves who release effluents unchecked. Excess of nickel concentration in water hampers the growth of fish amounting to their survival in 
question. This fish when eaten by people, causes skin rashes, asthma, eye diseases, and more dangerous consequences of damage to body implants like cardiac stents and valves, and orthopedic implants like plates, rods; damage or death of living cells; carcinogenesis of living cells, that are fatal when things go out of control. The reason behind the damage or death of living cells is believed to be due to oxidative reactions known as nickel induced Lipid Peroxidation (LPO). Hence it is better to keep a watch on the release of nickel through effluents and the total content of excessive nickel in the whole of the environment; so that the above mentioned hazards are avoided $^{10}$.

Water quality affected by contamination is checked in two steps. First, concentration of different chemicals is determined in the collected water samples. Here, water is considered as polluted if the concentrations of the pollutants are too high. Such checks are also called chemical indicators of water quality. The second method is to access the quality, appearance, and effect on to the fish, and other invertebrate organisms supported by the water body. A wide flora of fish and other living creatures in a water body shows minimal water pollution in such a body, and hence water quality is considered to be good. But if the case is opposite, where very less life is detected in water bodies, the pollution is considered to be very high and the available quality of fish is ipoor and their edibility is questionable.

\section{Methodology:-}

Processing of the fresh water fingerlings major carp Labeo rohita for study:-

Fresh water fingerlings major carp Labeo rohita of both sexes were collected from the local fish farm. The fish were stored in the aquarium with availability of oxygen and proper $\mathrm{pH}$. Experiments were commenced after acclimatizing the fishes to the lab condition for a period ranging from 15 to 20 days. Different concentration of Copper and Nickel were made by dissolving appropriate amount of analytical grade Copper chloride and Nickel sulphate in the fresh water. Fresh water fingerlings were exposed to it. After exposing to different concentration for different duration 2-3 fingerlings were remove and sacrifice for blood smear study. The thin blood smears were prepared for observing the cellular alterations in the blood cells. The smears were stained with Leishmann's stain and the observations were noted in a tabular form.

$\mathrm{LD}_{50}$ dose was studied for both the heavy metals and accordingly the ppm concentration was selected for the heavy metal study.

\section{Result And Discussion:-}

The results of hematological studies on fish Labeo rohita are shown in the following tables:

\begin{tabular}{|c|c|c|c|}
\hline $\begin{array}{c}\text { Concentration of } \\
\text { Copper Chloride }\end{array}$ & $\begin{array}{c}\text { Effect on RBC after Exposure for } \\
\text { 15 days }\end{array}$ & $\begin{array}{c}\text { Concentration } \\
\text { of Nickel Sulphate }\end{array}$ & $\begin{array}{c}\text { Effect on RBC after Exposure } \\
\text { for 15 days }\end{array}$ \\
\hline $1.0 \mathrm{ppm}$ & Cell membrane is damaged. & $40 \mathrm{ppm}$ & The cell membrane damaged. \\
\hline
\end{tabular}

\begin{tabular}{|c|l|c|c|}
\hline $\begin{array}{c}\text { Concentration of } \\
\text { Copper Chloride }\end{array}$ & $\begin{array}{c}\text { Effect on RBC after Exposure for } \\
\text { 30 days }\end{array}$ & $\begin{array}{c}\text { Concentration } \\
\text { of Nickel Sulphate }\end{array}$ & $\begin{array}{c}\text { Effect on RBC after Exposure } \\
\text { for 30 days }\end{array}$ \\
\hline $1.0 \mathrm{ppm}$ & $\begin{array}{l}\text { Size of the nucleus is reduced and } \\
\text { vacullation observed. }\end{array}$ & $40 \mathrm{ppm}$ & $\begin{array}{l}\text { The nucleus enlarged and } \\
\text { vacullation observed. }\end{array}$ \\
\hline
\end{tabular}

\begin{tabular}{|c|l|c|c|}
\hline $\begin{array}{c}\text { Concentration of } \\
\text { Copper Chloride }\end{array}$ & $\begin{array}{c}\text { Effect on RBC after Exposure for } \\
\mathbf{4 5} \text { days }\end{array}$ & $\begin{array}{c}\text { Concentration } \\
\text { of Nickel Sulphate }\end{array}$ & $\begin{array}{c}\text { Effect on RBC after Exposure } \\
\text { for 45 days }\end{array}$ \\
\hline $1.0 \mathrm{ppm}$ & $\begin{array}{l}\text { Cell membrane is destroyed and } \\
\text { nucleus shifts in position. }\end{array}$ & $40 \mathrm{ppm}$ & $\begin{array}{l}\text { The cell membrane is damaged } \\
\text { and vacullation observed. }\end{array}$ \\
\hline
\end{tabular}

\begin{tabular}{|c|l|c|c|}
\hline $\begin{array}{c}\text { Concentration of } \\
\text { Copper Chloride }\end{array}$ & $\begin{array}{c}\text { Effect on RBC after Exposure for } \\
\text { 15 days }\end{array}$ & $\begin{array}{c}\text { Concentration } \\
\text { of Nickel Sulphate }\end{array}$ & \multicolumn{2}{|c|}{$\begin{array}{c}\text { Effect on RBC after Exposure } \\
\text { for 15 days }\end{array}$} \\
\hline $2.0 \mathrm{ppm}$ & $\begin{array}{l}\text { Cell membrane is damaged and } \\
\text { vacullation observed. }\end{array}$ & $55 \mathrm{ppm}$ & $\begin{array}{l}\text { The nucleus shift from its } \\
\text { Position. }\end{array}$ \\
\hline
\end{tabular}

\begin{tabular}{|c|c|c|c|}
\hline $\begin{array}{c}\text { Concentration of } \\
\text { Copper Chloride }\end{array}$ & $\begin{array}{c}\text { Effect on RBC after Exposure for } \\
\text { 30 days }\end{array}$ & $\begin{array}{c}\text { Concentration } \\
\text { of Nickel Sulphate }\end{array}$ & $\begin{array}{c}\text { Effect on RBC after Exposure } \\
\text { for 30 days }\end{array}$ \\
\hline $2.0 \mathrm{ppm}$ & $\begin{array}{l}\text { Nucleus and the cell membrane is } \\
\text { damaged. }\end{array}$ & $55 \mathrm{ppm}$ & $\begin{array}{l}\text { The cell membrane is wrinkled } \\
\text { and vacullation observed. }\end{array}$ \\
\hline
\end{tabular}




\begin{tabular}{|c|l|c|c|}
\hline $\begin{array}{c}\text { Concentration of } \\
\text { Copper Chloride }\end{array}$ & $\begin{array}{c}\text { Effect on RBC after Exposure for } \\
\mathbf{4 5} \text { days }\end{array}$ & $\begin{array}{c}\text { Concentration } \\
\text { of Nickel Sulphate }\end{array}$ & $\begin{array}{c}\text { Effect on RBC after Exposure } \\
\text { for 45 days }\end{array}$ \\
\hline $2.0 \mathrm{ppm}$ & $\begin{array}{l}\text { Nucleus is enlarged, cell membrane } \\
\text { is wrinkled and damaged. }\end{array}$ & $55 \mathrm{ppm}$ & The nucleus damaged. \\
\hline
\end{tabular}

\begin{tabular}{|c|l|c|l|}
\hline $\begin{array}{c}\text { Concentration of } \\
\text { Copper Chloride }\end{array}$ & $\begin{array}{c}\text { Effect on RBC after Exposure for } \\
\mathbf{1 5} \text { days }\end{array}$ & $\begin{array}{c}\text { Concentration } \\
\text { of Nickel Sulphate }\end{array}$ & $\begin{array}{c}\text { Effect on RBC after Exposure } \\
\text { for 15 days }\end{array}$ \\
\hline $3.0 \mathrm{ppm}$ & $\begin{array}{l}\text { Cell membrane and nucleus are } \\
\text { damaged. }\end{array}$ & $70 \mathrm{ppm}$ & $\begin{array}{l}\text { The cell membrane damaged and } \\
\text { vacullation observed. }\end{array}$ \\
\hline
\end{tabular}

\begin{tabular}{|c|l|c|l|}
\hline $\begin{array}{c}\text { Concentration of } \\
\text { Copper Chloride }\end{array}$ & $\begin{array}{c}\text { Effect on RBC after Exposure for } \\
\mathbf{3 0} \text { days }\end{array}$ & $\begin{array}{c}\text { Concentration } \\
\text { of Nickel Sulphate }\end{array}$ & $\begin{array}{c}\text { Effect on RBC after Exposure } \\
\text { for 30 days }\end{array}$ \\
\hline $3.0 \mathrm{ppm}$ & $\begin{array}{l}\text { Nucleus damaged and vacullation } \\
\text { observed. }\end{array}$ & $70 \mathrm{ppm}$ & $\begin{array}{l}\text { The nucleus enlarged and shift in } \\
\text { position. }\end{array}$ \\
\hline
\end{tabular}

\begin{tabular}{|c|l|c|l|}
\hline $\begin{array}{c}\text { Concentration of } \\
\text { Copper Chloride }\end{array}$ & \multicolumn{1}{|c|}{$\begin{array}{c}\text { Effect on RBC after Exposure for } \\
\mathbf{4 5} \text { days }\end{array}$} & $\begin{array}{c}\text { Concentration } \\
\text { of Nickel Sulphate }\end{array}$ & $\begin{array}{c}\text { Effect on RBC after Exposure } \\
\text { for 45 days }\end{array}$ \\
\hline $3.0 \mathrm{ppm}$ & $\begin{array}{l}\text { Cell membrane and nucleus shift in } \\
\text { position. }\end{array}$ & $70 \mathrm{ppm}$ & $\begin{array}{l}\text { The cell membrane destroyed } \\
\text { and the nucleus enlarged and } \\
\text { damaged. }\end{array}$ \\
\hline
\end{tabular}

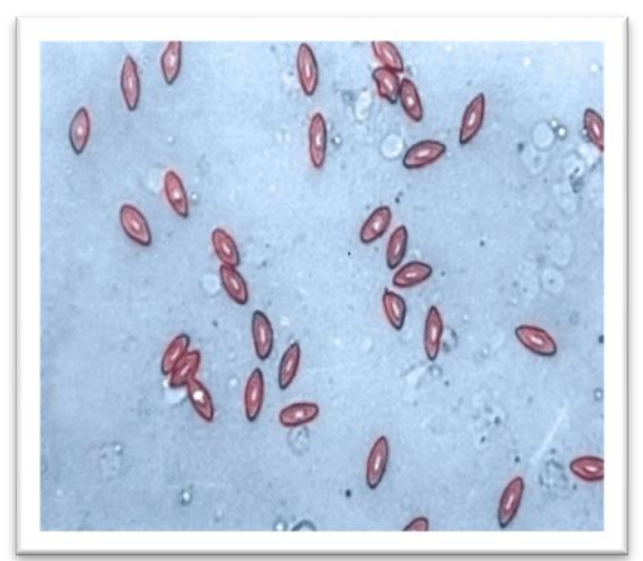

Fig. 1:- Normal blood smear of the fish Labeo rohita.

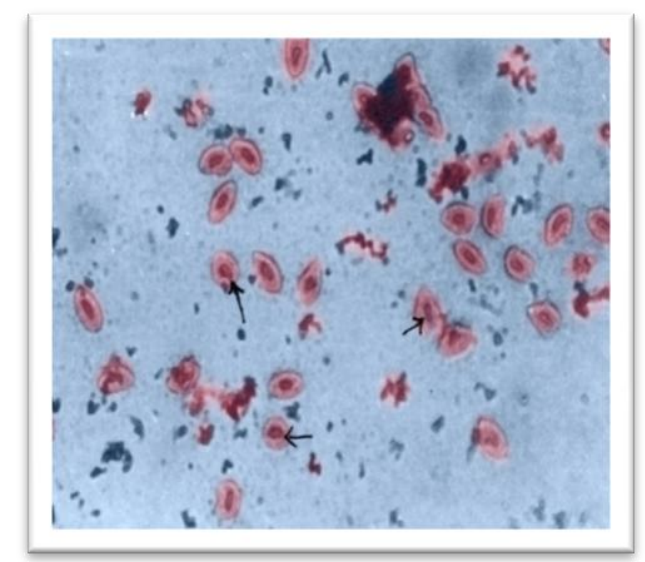

Fig. 2:- Nucleus shift from its position, cell membrane damaged and vaccullation is observed. 


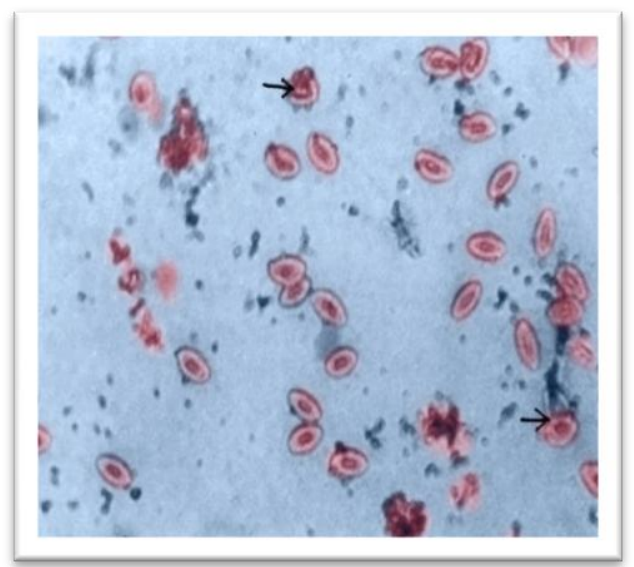

Fig. 3:- Vacullation and nucleus shift observed

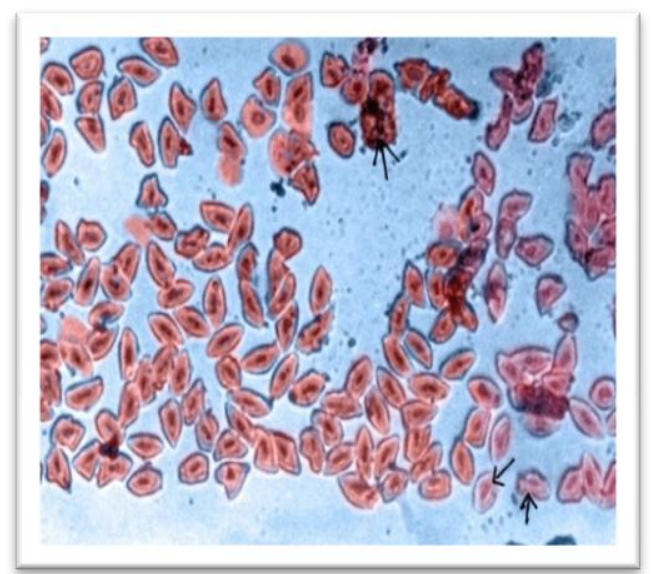

Fig. 4:- Deformities observed in the shape of the cell and cell membrane wrinkled

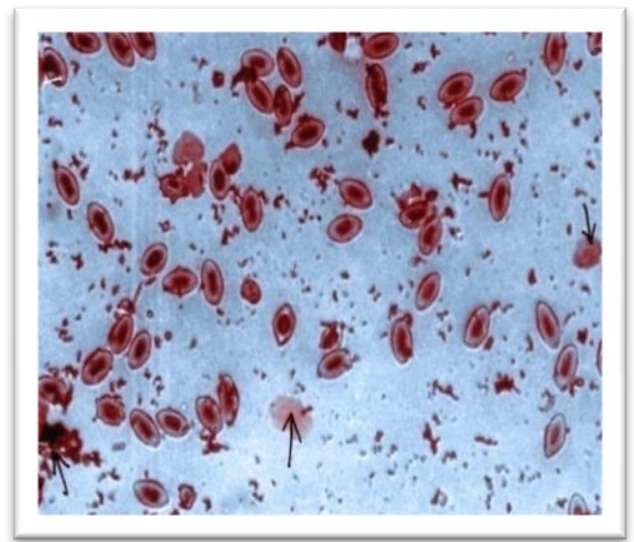

Fig. 5:- Vacullation, nucleus shift and Plasmolysis of cell content are observed.

\section{Conclusion:-}

The comparative study showed different results at different concentrations of heavy metals which are clearly stated in the tabular form. When fish was exposed to copper chloride in low and high concentration cell membrane was damaged, wrinkled, vacullation and nucleus shifted from normal position. Plasmolysis of cell was observed. This type of effects cause anemia in fish. Anemic condition in fish may lead to decrease in Oxygen carrying capacity; it may be due to injury caused to the RBCs. Reduction of RBC production coupled together with the destruction of previously present $\mathrm{RBC}$ on exposure of fish to the pollutant. ${ }^{5}$ The toxic chemicals present in the pollutants interfered 
with respiration, by causing coagulation in gills, which inhibits the enzyme system at mitochondrial levels resulting in the reduction of Oxygen consumption. When fish were exposed to nickel sulphate in low and high concentration the cell membrane is damaged and wrinkled, nucleus is more enlarged, vacullation is less observed but nucleus shift is observed.

Comparing both the chemicals together it was found that Copper chloride showed more damage to the RBCs than Nickel sulphate. On studying the $\mathrm{LD}_{50}$ level of both this chemicals it was observed that the low concentration of copper chloride was toxic to the fish where as concentration of nickel sulphate was kept high to show visible toxicity in fish cells. This aspect of study clearly implied lowering of its nutritional value in particular and commercial losses in general with health related problems for the end user.

\section{References:-}

1. Anusha. (1994). Effect of endosulfan on oxygen consumption, red blood cell count and food utilization of fresh water fish Clarius dussumieri, J. Environ. Toxicol., 4(1), 1-63, 33-36.

2. Baldwin. (2003). Sublethal Effects Of Copper on Coho Salmon: Impacts on No overlapping Receptor Pathways in the Peripheral Olfactory Nervous System, Environmental Toxicology and Chemistry 22(10), 2266 - 2274.

3. Bervoets L, Blust R, Verheyen R. (2001). Accumulation of metals in tissues of three spined sticklebacks (Gasterosteus aculeatus) from natural fresh waters. Ecotoxicology and Environmental Safety, 48 (2): 117-27.

4. Bradi and Heike. (2005). Heavy Metals in the Environment: Origin, Interaction and Remediation, Elsevier/Academic Press, London, 22-29.

5. Chaffai AH, Romeo M, Abed EL. (1996). Heavy metals in different fishes from Middle Eastern coast of Tunisia. Bulletin of Environmental Contamination and Toxicology, 56: 766-773.

6. Dural M, Goksu MZL, Ozak AA, Baris D. (2007). Bioaccumulation of some heavy metals in different tissues of Dicentrarchus labrax L, 1758, Sparus aurata L, 1758 and Mugil cephalus L, 1758 from the Camlik lagoon of the eastern cost of Mediterranean (Turkey). Environmental Monitoring and Assessment, 118(1-3): 65-74.

7. Karadede H, Oymak SA, Unlu E. (2004). Heavy metals in mullet, Liza abu, and cat fish. Silurus triotegus, from the Ataturk Dam Lake (Euphrates), Turkey. Environmental International, 30: 183-188.

8. Kotze P, Du Preez HH, Van Vuren JHJ. (1999). Bioaccumulation of copper and zinc in Orechromis mossambicus and Clarias gariepinus, from the Olifants River, Mpumalanga, South Africa. Water SA, 25(1): 99110.

9. Mendil D, Uluozlu OD. (2007). Determination of trace metals in sediment and five fish species from lakes in Tokat, Turkey, Food Chemistry, 101: 739-745. Polish Journal of Environment Study (2006); Vol.15,No.3, 375382.

10. Rao LM, Padmaja G. (2000). Bioaccumulation of heavy metals in M. cyprinoids from the harbor waters of Vishakapatinam. Bulletin of Pure Applied Science, 19A (2): 77-85.

11. Scharenberg W, Gramann P, Pfeiffer WH. (1994). Bioaccumulation of heavy metals and organochlorine in a lake ecosystem with special reference to bream (Abramis brama). The Science of Total Environment, 14: 19797.

12. Shah AI. and Vyas BM. (2015). Relative study of copper toxicity on aquatic life and human health, J. Environ. Res. Develop., 9(3A), 884-888.

13. Wright, David A and Pamela Welbourn. (2002). Environmental Toxicology, Cambridge University Press, Cambridge, U.K., 147-158. 